\title{
RESEARCH PAPER \\ Pre- and postharvest attributes of muskmelon cultivars for fresh-cut cubes
}

\author{
Christian Krarup, Cristián Jacob, and Samuel Contreras \\ Departamento de Ciencias Vegetales, Pontificia Universidad Católica de Chile, Vicuña Mackenna 4860, \\ Santiago, Chile.
}

\begin{abstract}
C. Krarup, C. Jacob, and S. Contreras. 2016. Pre- and postharvest attributes of muskmelon cultivars for fresh-cut cubes. Cien. Inv. Agr. 43(1):43-51. The choice of the appropriate cultivar is a critical factor for obtaining a successful crop and for satisfying the needs of the industry and consumers. Nine commonly used or recently available varieties of cantaloupe melons (Cucumis melo L. Group Cantalupensis) were evaluated in two locations with the objective of selecting cultivars ad hoc for processing as fresh-cut cubes. Overall, the yield ( 30 to $45 \mathrm{tha}^{-1}$ ) and quality, including mainly the fruit size and soluble solids concentration (SSC), varied between locations, but the relative performance of cultivars was similar. The cultivars showed significant differences in attributes that are relevant for the industry and the consumer: color (from yellow to deep orange), SSC (from 8.7 to 14.7\%), firmness (11.2 to 32.8 $\mathrm{N}$ ), and chilling injury after refrigerated storage for 18 days at $0{ }^{\circ} \mathrm{C}$ (from none to slight) and after 3 additional days at $20^{\circ} \mathrm{C}$ (from none to severe). Cultivars such as Diva, Fiji, and Glamour presented attributes that make them especially valuable for the fresh-cut processing industry.
\end{abstract}

Key words: Cantaloupe, color, chilling injury, Cucumis melo, firmness, soluble solids, storage.

\section{Introduction}

Fresh-cut products are defined as fruits or vegetables that have been trimmed, peeled and/or cut into a $100 \%$ usable product that is packaged to offer consumers convenience, flavor and high nutrition while still maintaining freshness (Beaulieu and Gorny, 2014). Fresh-cut produce sales worldwide have grown significantly during the past few years, especially in developed countries; out of the total produce sales, fresh-cut sales have

Received April 8, 2015. Accepted December 9, 2015. Corresponding author: ckrarup@uc.cl an estimate share of $18 \%$ in Europe, $9 \%$ in the United States, and 5\% in Australia (Florkowski et al., 2014). In terms of value, fresh-cut sales in the United States in 2012 were projected at \$28 billion annually, including US\$ 11 billion sales in all grocery retail channels and US\$ 17 billion in all foodservice channels, with melons being a significant part of this segment, representing $8.4 \%$ as individual fresh-cut fruit and part of the $28.8 \%$ of the mixed cut fruits at the retail level (Cook, 2014). In general, it has been estimated that fresh-cut fruits currently represent 7 to $10 \%$ of the total fresh-cut sales in different countries and show significant growth rates in most of 
them (Florkowski et al., 2014). To maintain the momentum created by steady growth, among other challenges, the processing industry needs high-quality products (Dean, 2013).

Quality, the degree of excellence of fresh-cut fruits, is a combination of attributes, characteristics or properties that give each commodity value in terms of human food (Kader, 1999). Cantaloupe melons used as raw material for fresh-cut cubes should have certain attributes, such as a flesh with a deep orange color, high firmness, and high soluble solids content, coupled with the distinctive aroma and flavor that determine high quality in these melons (Krarup, 2010; Cantwell, 2014). The storage potential of whole fruit at low temperatures is an important characteristic for transport, storage, processing and marketing, and the ideal fresh-cut fruit model must also have excellent storability (Munira et al., 2013).

The storage of cantaloupes at temperatures between 2 and $7{ }^{\circ} \mathrm{C}$ and relative humidity (RH) $\geq 95 \%$ is widely used to maintain external visual quality and characteristics of the flesh and to reduce dehydration and postharvest decay (Kader, 2002; Fallik et al., 2005). A temperature range is given because these melons have variable sensitivity to chilling injury (CI), depending on the cultivar, the maturity stage, the temperature used below the critical minimum, and the time or period of exposure. CI in these fruits appears as a result of exposure to low temperatures that cause various physiological changes, such as loss of membrane integrity and functionality, change in the activity of antioxidant enzymes, accumulation of ethanol and acetaldehyde, etc. (Fogelman et al., 2011). Eventually, physiological disorders cause visible external symptoms on the epidermis of the fruit and increase susceptibility to diseases, impairing visual quality, aroma and flavor (Fallik et al., 2005; Krarup et al., 2009). Thus, CI becomes a limiting factor for the prolonged storage and long-distance transport of muskmelons at temperatures between 0 and $2{ }^{\circ} \mathrm{C}$ (Krarup et al., 2009).
New breeding technologies and increasing knowledge have allowed breeders to overcome genetic, physiological, and technical barriers that have delayed and hindered the improvement of melon, mainly in productivity and fruit quality (Nuñez-Palenius et al., 2008). Recent progress has made available a significant and increasing number of new cultivars of different muskmelon types (Eastern, Tuscan, Western Shipper, etc.). The choice of the appropriate cultivar or variety is one of the most critical production inputs for growers, but despite the increasing introduction of new varieties, there is less public variety testing than ever before (Williams and Roberts, 2002), and there are no known evaluations with the objective of selecting melons cultivars that combine specific pre- and postharvest characteristics as raw material for fresh-cut cubes (Krarup et al., 2009; Ohashi et al., 2009).

The objective of this research was to evaluate the pre- and postharvest attributes of nine cantaloupe cultivars for fresh-cut cubes, considering that in produce intended for the industry, one of the primary challenges is combining field yield with the quality that the industry and consumers are looking for.

\section{Materials and methods}

\section{Plant material and crop production}

Nine cantaloupe cultivars (Cucumis melo L. Group Cantalupensis) were evaluated in this study: Colima and PS4038 (Seminis Vegetable Seeds, St. Louis, MO, USA), Diva (Origene Seeds, Givat Brenner, Israel), Glamour (Sakata Seed Corporation, Kanagawa, Japan), and Fiji, HMX0592, HMX9608, Navigator, and Venezia (HM Clause, Davis, CA, USA). Sowing was performed on October 1, 2012, in plastic trays with a mixture of peat moss and perlite (2:1), and the plants were grown in an unheated greenhouse. Two production sites were used: transplanting 
was performed $34 \mathrm{~d}$ after sowing in the Peñaflor site (sandy loam soil at $33^{\circ} 37^{\prime} \mathrm{S}, 7^{\circ} 53^{\prime} \mathrm{W}$ ) and $40 \mathrm{~d}$ after sowing in the Curacaví site (loamy soil at $33^{\circ} 26^{\prime} \mathrm{S}, 71^{\circ} 01^{\prime} \mathrm{W}$ ). Both sites are located in the central part of Chile and have a Mediterranean, semi-arid climate, without rain during the growth period. A randomized complete block design with five replicates was used at each site. Each block consisted of a row with nine 5-m-long experimental units. The distance between rows was $1.8 \mathrm{~m}$ with 3 plants per meter in the row (15 plants in each experimental unit). Crop management was performed according to common local cultivation practices with drip irrigation and a 1-m-wide white plastic mulch strip in each row.

\section{Yield and fruit quality at harvest}

Harvest began 113 and 117 days after sowing in Peñaflor and Curacaví, respectively. The fruits were harvested three times a week using specific visual maturity indicators for each cultivar, such as the degree of fruit abscission, epidermal net development, and skin color. For yield assessment, all the harvested fruits were weighed in the field. Ten representative fruits of each cultivar were brought to the laboratory, where they were weighed and cut in the equatorial plane. Flesh width was determined with a digital Vernier caliper at two opposite sites. Flesh color was measured at two opposite sites, midway between epidermis and seed cavity, using a colorimeter (CR-400; Konica Minolta Sensing Inc., Osaka, Japan); the $\mathrm{a}^{*}$ dimension, which runs from green $(-60)$ to red $(+60)$, is reported because its value best indicates the variation in perceived orange color (Konica Minolta Sensing, Inc., 2007). For each fruit, the soluble solids concentration (SSC) was determined by the extraction of four equidistant cylinders ( $\sim 40$ $\mathrm{mm}^{3}$ ) from the middle of the flesh; each cylinder was squeezed with a hand press, and the SSC of the juice measured with a digital refractometer (Master T; Atago Co., Tokyo, Japan). The flesh firmness (Newtons) was determined by four equidistant measurements in the middle of the flesh using an automatic fruit texture analyzer equipped with an 8-mm tip (GS-15; Guss Manufacturing Ltd., Cape Town, South Africa). Finally, the seeds were removed, and each half of the fruit was peeled with a melon peeler (PerfectPeeler MP-100; Univex Corp., Salem, NH); then, the pulp was weighed. The fresh-cut yield (FCY) was calculated according to the following equation: FCY $(\%)=$ flesh fresh weight/ melon fresh weight $\times 100$.

\section{Postharvest storage}

In the laboratory, ten representative fruits of each cultivar were washed for $1 \mathrm{~min}$ in a $200-\mathrm{ppm}$ sodium hypochlorite solution, dried at room temperature, and weighed. Each fruit was packaged in a sealed plastic bag with six perforations of $6 \mathrm{~mm}$ in diameter, stored for $18 \mathrm{~d}$ at $0{ }^{\circ} \mathrm{C}$ and $\geq 98 \% \mathrm{RH}$, removed from the bags and left for 3 $\mathrm{d}$ at $20{ }^{\circ} \mathrm{C}$ and $\sim 55 \% \mathrm{RH}$, simulating long-range transport and a short marketing period (Krarup et al., 2009). After the 21-d storage period, the flesh color, soluble solids concentration, firmness, and weight were determined. External CI symptoms were assessed after the 18- and 21-d periods using a modified version of the quality visual scale described by Yang et al. (2003): 0, no damage to traces ( 0 to $1 \%$ surface symptoms); 1, mild (1.1 to $5 \%$ ); 2 , moderate (5.1 to $15 \%) ; 3$, severe (15.1 to $30 \%)$; and 4 , extreme (>30\%). Spots, superficial lesions, and soaked tissue were considered CI symptoms (Yang et al., 2003; Krarup et al., 2009).

\section{Data analysis}

An analysis of variance was carried out for the data of each location. The significant differences among cultivars $(\mathrm{P} \leq 0.05)$ were separated using the least significant difference test (LSD; $\alpha=0.05)$. 


\section{Results and discussion}

\section{Plant yield}

No significant differences were observed in fruit yield $\left(\mathrm{kg} \cdot \mathrm{plant}^{-1}\right)$ among cultivars in each location, although the cultivars differed in fruit mass and the number of fruits per plant (Table 1). The average number of fruits per plant in Curacaví and Peñaflor was 1.8 and 2.0, respectively, close to the national average estimated for the crop in Chile (INE, 2010). In all cultivars, the individual fruit weight was higher in Curacaví (19 to $42 \%$ higher depending on the cultivar) than in Peñaflor, resulting in the higher yields obtained at that site. Smaller fruit size can occur in situations of low water availability during fruit development (Sensoy et al., 2007), and the sandy loam soil of Peñaflor had lower water retention. Considering a usual plant population of 16,666 plants $\cdot \mathrm{ha}^{-1}$, the average fruit yields in Peñaflor and Curacaví were close to 30 and $45 \mathrm{tha}^{-1}$, respectively, and are similar to the yield ranges shown in other cantaloupe trials (Saha and Sutterer, 2014).

\section{Quality at harvest}

In both locations, significant differences among cultivars were observed for all of the quality attributes evaluated at harvest (Tables 2 and 3). Colima, one of the commonly used cultivars in Chile, and PS4038 presented some of the lowest values in color, SSC and firmness, demonstrating the importance of evaluating new cultivars to be used for fresh-cut cubes. Flesh color represents an important visual attribute for consumer acceptance; a deep and intense orange color is expected (Krarup, 2010; Cantwell, 2014). 'Diva' and 'Fiji' presented the highest values of $\mathrm{a}^{*}(\geq 15)$, which is associated with the required color; 'Glamour' presented the lowest value $(\leq 10)$, exhibiting a pale orange flesh.

SSC requirement is market dependent; for the United States, the SSC should be $\geq 9 \%$ (Kader, 2002; Cantwell, 2014), while the Japanese prefer sweeter melons, with an SSC of $\geq 13 \%$ (Sakata and Sugiyama, 2002). The cultivars consistently presented higher SSC values in Peñaflor than in Curacaví (Tables 2 and 3), which could be associated with the lower water availability and small size (Sensoy et al., 2007; Zeng et al., 2009) of the fruits that were harvested in Peñaflor. However, the relative ranking of cultivars was similar in both locations, with Fiji, Glamour, HMX0592, and Venezia having higher SSC (greater than 12\% and $13 \%$ in Curacaví and Peñaflor, respectively).

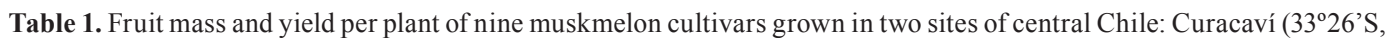
$\left.71^{\circ} 01^{\prime} \mathrm{W}\right)$ and Peñaflor ( $\left.33^{\circ} 37^{\prime} \mathrm{S}, 70^{\circ} 53^{\prime} \mathrm{W}\right)$.

\begin{tabular}{|c|c|c|c|c|c|c|}
\hline \multirow{3}{*}{ Cultivar } & \multicolumn{3}{|c|}{ Curacaví } & \multicolumn{3}{|c|}{ Peñaflor } \\
\hline & \multirow{2}{*}{$\begin{array}{l}\text { Fruit mass } \\
\mathrm{kg} \text { fruit }^{-1}\end{array}$} & \multicolumn{2}{|c|}{ Fruit yield per plant } & \multirow{2}{*}{$\begin{array}{l}\text { Fruit mass } \\
\text { kg fruit }^{-1}\end{array}$} & \multicolumn{2}{|c|}{ Fruit yield per plant } \\
\hline & & number & $\mathrm{kg}$ & & number & $\mathrm{kg}$ \\
\hline Colima & $1.46 b^{2}$ & $2.2 \mathrm{ab}$ & 3.24 & $1.17 \mathrm{ab}$ & $1.6 \mathrm{~b}$ & 1.92 \\
\hline Diva & $1.29 \mathrm{c}$ & $1.7 \mathrm{~cd}$ & 2.20 & $1.08 \mathrm{bc}$ & $1.8 \mathrm{~b}$ & 1.97 \\
\hline Fiji & $1.38 \mathrm{bc}$ & $1.6 \mathrm{~d}$ & 2.18 & $1.11 \mathrm{bc}$ & $1.7 \mathrm{~b}$ & 1.85 \\
\hline Glamour & $1.07 \mathrm{~d}$ & $2.6 \mathrm{a}$ & 2.83 & $0.79 \mathrm{~d}$ & $2.7 \mathrm{a}$ & 2.10 \\
\hline HMX0592 & $1.42 \mathrm{bc}$ & $2.0 \mathrm{bcd}$ & 2.81 & $1.00 \mathrm{c}$ & $1.8 \mathrm{~b}$ & 1.78 \\
\hline HMX9608 & $1.46 \mathrm{~b}$ & $1.9 \mathrm{bcd}$ & 2.83 & $1.03 \mathrm{bc}$ & $1.8 \mathrm{~b}$ & 1.87 \\
\hline Navigator & $1.47 \mathrm{~b}$ & $1.7 \mathrm{~cd}$ & 2.43 & $1.17 \mathrm{ab}$ & $1.5 \mathrm{~b}$ & 1.79 \\
\hline PS4038 & $1.82 \mathrm{a}$ & $1.8 \mathrm{bcd}$ & 3.27 & $1.29 \mathrm{a}$ & $1.7 \mathrm{~b}$ & 2.23 \\
\hline Venezia & $1.36 \mathrm{bc}$ & $2.1 \mathrm{bc}$ & 2.81 & $1.14 \mathrm{abc}$ & $1.6 \mathrm{~b}$ & 1.87 \\
\hline $\mathrm{P}_{\text {value }}{ }^{1}$ & $<0.001$ & 0.003 & 0.050 & $<0.001$ & 0.030 & 0.947 \\
\hline
\end{tabular}

${ }^{1}$ Probability value from the analysis of variance.

${ }^{2}$ Means in the same column with different letter(s) are significantly different according to a least significant difference test $(\alpha \leq 0.05)$. 
Table 2. Fruit attributes at harvest and after 21 days of storage $\left(18\right.$ days at $0{ }^{\circ} \mathrm{C}+3$ days at $\left.20^{\circ} \mathrm{C}\right)$ of nine melon cultivars produced in Curacaví (Chile).

\begin{tabular}{|c|c|c|c|c|c|c|c|c|}
\hline \multirow[b]{2}{*}{ Cultivar } & \multicolumn{5}{|c|}{ At harvest } & \multicolumn{3}{|c|}{21 days after harvest } \\
\hline & Color $\left(a^{*}\right)$ & $\operatorname{SSC}(\%)$ & $\begin{array}{l}\text { Firmness } \\
(\mathrm{N})\end{array}$ & $\mathrm{FCY}^{1}(\%)$ & $\begin{array}{l}\text { Pulp width } \\
\text { (cm) }\end{array}$ & Color $\left(a^{*}\right)$ & $\begin{array}{l}\text { SSC } \\
(\%)\end{array}$ & $\begin{array}{c}\text { Firmness } \\
(\mathrm{N})\end{array}$ \\
\hline Colima & $11.8 \mathrm{de}^{3}$ & $9.3 \mathrm{e}$ & $11.6 \mathrm{~d}$ & $50.2 \mathrm{ab}$ & $3.1 \mathrm{~cd}$ & $12.6 \mathrm{c}$ & $8.1 \mathrm{~d}$ & $10.4 \mathrm{de}$ \\
\hline Diva & $17.1 \mathrm{a}$ & $11.1 \mathrm{~cd}$ & $11.9 \mathrm{~d}$ & $47.7 \mathrm{c}$ & $3.0 \mathrm{~cd}$ & $16.8 \mathrm{a}$ & $11.1 \mathrm{ab}$ & $14.1 \mathrm{~cd}$ \\
\hline Fiji & $15.5 \mathrm{~b}$ & $12.6 \mathrm{a}$ & $27.5 \mathrm{~b}$ & $49.8 \mathrm{ab}$ & $3.8 \mathrm{ab}$ & $15.4 \mathrm{~b}$ & $11.9 \mathrm{a}$ & $29.5 \mathrm{a}$ \\
\hline Glamour & $9.1 \mathrm{f}$ & $12.4 \mathrm{ab}$ & $32.8 \mathrm{a}$ & $48.4 \mathrm{bc}$ & $2.8 \mathrm{de}$ & $8.4 \mathrm{e}$ & $11.6 \mathrm{ab}$ & $26.7 \mathrm{ab}$ \\
\hline HMX0592 & $11.1 \mathrm{e}$ & $12.1 \mathrm{acb}$ & $19.9 \mathrm{c}$ & $47.9 \mathrm{c}$ & $2.5 \mathrm{e}$ & $11.1 \mathrm{~d}$ & $9.5 \mathrm{~cd}$ & $24.4 \mathrm{~b}$ \\
\hline HМX9608 & $12.8 \mathrm{~cd}$ & $11.3 \mathrm{bcd}$ & $13.5 \mathrm{~d}$ & $47.1 \mathrm{c}$ & $3.4 \mathrm{bc}$ & $11.6 \mathrm{~d}$ & $10.4 \mathrm{bc}$ & $9.0 \mathrm{e}$ \\
\hline Navigator & $13.6 \mathrm{c}$ & $10.8 \mathrm{~d}$ & $13.5 \mathrm{~d}$ & $50.2 \mathrm{ab}$ & $4.0 \mathrm{a}$ & $13.2 \mathrm{c}$ & $9.0 \mathrm{~cd}$ & $14.2 \mathrm{~cd}$ \\
\hline PS 4038 & $12.1 \mathrm{de}$ & $8.7 \mathrm{e}$ & $11.4 \mathrm{~d}$ & $50.4 \mathrm{a}$ & $3.0 \mathrm{~cd}$ & $11.4 \mathrm{~d}$ & $9.2 \mathrm{~cd}$ & $10.1 \mathrm{de}$ \\
\hline Venezia & $13.8 \mathrm{c}$ & $12.3 \mathrm{abc}$ & $36.4 \mathrm{a}$ & $49.0 \mathrm{abc}$ & $3.7 \mathrm{ab}$ & $12.6 \mathrm{c}$ & $11.6 \mathrm{ab}$ & $16.9 \mathrm{c}$ \\
\hline$P_{\text {value }}^{2}$ & $\leq 0.001$ & $\leq 0.001$ & $\leq 0.001$ & $\leq 0.001$ & $\leq 0.001$ & $\leq 0.001$ & $\leq 0.001$ & $\leq 0.001$ \\
\hline
\end{tabular}

${ }^{1} \mathrm{FCY}$ : Fresh-cut yield $=$ flesh fresh $\cdot$ weight melon fresh weight ${ }^{-1} \cdot 100$.

${ }^{2}$ Probability value from the analysis of variance.

${ }^{3}$ Means in the same column with different letter(s) are significantly different according to a least significant difference test $(\alpha \leq 0.05)$.

In contrast, 'Colima' and 'PS4038' had lower SSC values (approximately $9.0 \%$ and $11.5 \%$ in Curacaví and Peñaflor, respectively).

Firmness is an important quality attribute for fresh-cut cubes. During cube storage, enzyme activity decreases the firmness and visual quality of the flesh (Silveira et al., 2011; Cantwell, 2014). The initial firmness of the melon flesh for fresh-cut products must be high (Munira et al., 2013). The cultivars Glamour, Venezia, and Fiji exhibited adequate levels of firmness in both locations $(\geq 25 \mathrm{~N})$, in contrast to the cultivars PS4038, HMX9608, Navigator, and Colima, which had lower firmness values $(\leq 15$ $\mathrm{N}$, Tables 2 and 3).

The needs of the consumers for fresh-cut melons are not only satisfied with adequate flesh color, sugar content and firmness, they also require a typical flavor and an appropriate cube size (Krarup, 2010; Munira et al., 2013). The flavors were different among cultivars, but repeated tasting showed that all cases varied from acceptable to excellent depending on the taster. The industrial production of fresh-cut melons results in cubes with a width corresponding to the thickness of the flesh in the equatorial plane. In Curacaví, the cultivars Navigator, Fiji, and Venezia presented the highest flesh width $(4.0,3.8$, and $3.7 \mathrm{~mm}$, respectively, Table 2), and these values resulted in larger cubes. In Peñaflor, the cultivars Glamour, HMX9608, and Fiji had less flesh width (2.1, 2.2, and $2.4 \mathrm{~mm}$, respectively, Table 3), resulting in smaller, nearly isodiametric and more attractive cubes.

To reach an appropriate degree of efficiency in fresh-cut processing, melons that maximize yields are required (Beaulieu and Gorny, 2014). Although all of the cultivars presented a FCY close to $50 \%$ in both locations, there were small but significant differences between cultivars, up to $3.2 \%$ in Curacaví and $6.2 \%$ in Peñaflor (Table 2 and 3), which at the industry level represent high economic value.

\section{Quality at postharvest}

After $21 \mathrm{~d}$ of storage, the relative classification of cultivars according to attributes of color, SSC, and firmness was similar to that at the moment of harvest (Tables 2 and 3). In general, no significant 
variation in pulp color or SSC was observed after storage, confirming observations of other authors (Cantwell, 2014; Munira et al., 2013). Firmness, as expected, was the attribute most affected by storage, with generally lower values at the end of the period. However, Fiji, Glamour, HMX0592 and Venezia after storage still were quite firm, even firmer than the other cultivars before storage, and still had a crunchy flesh. Loss of firmness during the storage of fresh-cut melons is a natural process, even under low temperature, and severely affects the desirable firmness. Some treatments to prevent softness and preserve quality have been proposed (Portela and Cantwell., 1998; Silveira et al., 2011), but the use of naturally firmer cultivars, such as those reported here, would be a better option; thus, this is an indispensable trait for evaluations.

\section{Chilling injury after storage periods}

The CI response of the cultivars at the end of the cold storage and after three days at ambient temperature is presented in Table 4. After $18 \mathrm{~d}$ at 0 ${ }^{\circ} \mathrm{C}$, fruits of the different cultivars presented only traces or no symptoms of CI, with the exception of
Colima and PS4038, whose fruits exhibited a mild to moderate level of symptoms. After $3 \mathrm{~d}$ at $20^{\circ} \mathrm{C}$, fruits from 'Diva', 'Fiji', and 'Glamour' still had no CI symptoms, while fruits from 'Colima' and 'PS4038' showed moderate to severe CI symptoms (Table 4). The genotypic variation in the sensitivity of cantaloupe melons to $\mathrm{CI}$ has been reported (Krarup et al., 2009), and 'Colima' and 'Glamour' were expected to present high and low sensitivity to CI, respectively (Laínez and Krarup, 2008; Krarup et al., 2009; Munira et al., 2013). Interestingly, Fiji, a cultivar with high quality traits, had no CI symptoms. Although CI symptoms are not visually evident in the pulp, the lack of aroma, the presence of off flavors, and the incidence of disease may severely affect the quality of the fruits for fresh-cut products after cold storage (Fallik et al., 2005; Krarup et al., 2009). It is noteworthy that some cultivars showed no to negligible visible symptoms of CI after three weeks, a period that would permit long-distance shipping or protracted processing.

In conclusion, the results of this study show that cultivar evaluations should be made at more than one site because yield and quality results are variable between sites, although the relative performances of cultivars do not vary notably.

Table 3. Fruit attributes at harvest and after 21 days of storage $\left(18\right.$ days at $0{ }^{\circ} \mathrm{C}+3$ days at $\left.20^{\circ} \mathrm{C}\right)$ of nine melon cultivars produced in Peñaflor (Chile).

\begin{tabular}{|c|c|c|c|c|c|c|c|c|}
\hline \multirow[b]{2}{*}{ Cultivar } & \multicolumn{5}{|c|}{ At harvest } & \multicolumn{3}{|c|}{21 days after harvest } \\
\hline & Color (a*) & $\operatorname{SSC}(\%)$ & $\begin{array}{l}\text { Firmness } \\
(\mathrm{N})\end{array}$ & $\mathrm{FCY}^{1}(\%)$ & $\begin{array}{l}\text { Pulp width } \\
\text { (cm) }\end{array}$ & Color $\left(\mathrm{a}^{*}\right)$ & SSC $(\%)$ & $\begin{array}{c}\text { Firmness } \\
(\mathrm{N})\end{array}$ \\
\hline Colima & $14.1 \mathrm{bc}^{3}$ & $11.8 \mathrm{de}$ & $15.2 \mathrm{~d}$ & $53.0 \mathrm{a}$ & $2.9 \mathrm{ab}$ & $12.6 \mathrm{~d}$ & $11.6 \mathrm{c}$ & $7.3 \mathrm{c}$ \\
\hline Diva & $17.5 \mathrm{a}$ & $13.0 \mathrm{abcd}$ & $28.4 \mathrm{c}$ & $47.7 \mathrm{bc}$ & $3.0 \mathrm{ab}$ & $17.2 \mathrm{a}$ & $11.3 \mathrm{c}$ & $11.0 \mathrm{c}$ \\
\hline Fiji & $14.9 \mathrm{bc}$ & $13.9 \mathrm{a}$ & $31.0 \mathrm{bc}$ & $48.8 \mathrm{bc}$ & $2.4 \mathrm{~cd}$ & $15.5 \mathrm{~b}$ & $13.9 \mathrm{ab}$ & $24.5 \mathrm{a}$ \\
\hline Glamour & $10.2 \mathrm{~d}$ & $14.0 \mathrm{a}$ & $35.6 \mathrm{~b}$ & $49.8 \mathrm{abc}$ & $2.1 \mathrm{~d}$ & $10.1 \mathrm{e}$ & $13.3 \mathrm{bc}$ & $18.3 \mathrm{~b}$ \\
\hline HMX0592 & $13.2 \mathrm{c}$ & $13.7 \mathrm{ab}$ & $30.9 \mathrm{bc}$ & $46.9 \mathrm{c}$ & $2.8 \mathrm{ab}$ & $12.1 \mathrm{~d}$ & $13.1 \mathrm{bc}$ & $26.5 \mathrm{a}$ \\
\hline HMX9608 & $12.8 \mathrm{c}$ & $12.1 \mathrm{cde}$ & $12.9 \mathrm{~d}$ & $49.3 \mathrm{bc}$ & $2.2 \mathrm{~d}$ & $12.3 \mathrm{~d}$ & $11.9 \mathrm{c}$ & $10.0 \mathrm{c}$ \\
\hline Navigator & $15.8 \mathrm{ab}$ & 12.3 bcde & $15.4 \mathrm{~d}$ & $49.4 \mathrm{bc}$ & $2.7 \mathrm{bc}$ & $14.4 \mathrm{c}$ & $12.2 \mathrm{c}$ & $16.3 \mathrm{~b}$ \\
\hline PS 4038 & $13.8 \mathrm{bc}$ & $11.3 \mathrm{e}$ & $12.5 \mathrm{~d}$ & $53.1 \mathrm{a}$ & $3.1 \mathrm{a}$ & $12.2 \mathrm{~d}$ & $11.4 \mathrm{c}$ & $9.2 \mathrm{c}$ \\
\hline Venezia & $12.0 \mathrm{~cd}$ & $13.3 \mathrm{abc}$ & $41.7 \mathrm{a}$ & $51.1 \mathrm{ab}$ & $3.1 \mathrm{a}$ & $12.0 \mathrm{~d}$ & $14.7 \mathrm{a}$ & $18.3 \mathrm{~b}$ \\
\hline $\mathrm{P}_{\text {value }}^{2}$ & $<0.001$ & $<0.001$ & $<0.001$ & 0.004 & $<0.001$ & $<0.001$ & $<0.001$ & $<0.001$ \\
\hline
\end{tabular}

${ }^{1}$ FCY: Fresh-cut yield $=$ flesh fresh $\cdot$ weight melon fresh weight ${ }^{-1} \cdot 100$.

${ }^{2}$ Probability value from the analysis of variance.

${ }^{3}$ Means in the same column with different letter(s) are significantly different according to a least significant difference test $(\alpha \leq 0.05)$. 
The specific quality traits that are measured for melon fruits intended for processing of freshcut cubes indicate that some cultivars could be significantly better than others for that purpose. The higher color, SSC and firmness, and the low CI of some cultivars after storage, such as Diva, Fiji and Glamour, confirm the need for and importance of evaluating new cultivars of melons specifically for the fresh-cut processing industry.

\section{Acknowledgements}

This research was conducted with financial support from the Fondo de Innovación Agropecuaria (FIA) (Chile) through the project PYT-2008-0207 "Generación de oferta nacional y demanda internacional de melón y sandía para procesados frescos".

\section{Resumen}

C. Krarup, C. Jacob y S. Contreras. 2016. Atributos de pre y poscosecha de melones reticulados para procesados frescos. Cien. Inv. Agr. 43(1):43-51. La elección del cultivar apropiado es un factor crítico para la obtención de una producción exitosa y para satisfacer las necesidades de la industria y los consumidores. Nueve cultivares de melón reticulado (Cucumis melo L. Group Cantalupensis) de uso común o reciente disponibilidad se evaluaron en dos localidades con el objetivo de seleccionar cultivares apropiados para la elaboración de cubos mínimamente procesados. En general, el rendimiento $\left(30 \mathrm{a} 45 \mathrm{t} \mathrm{ha}^{-1}\right)$ y la calidad, principalmente el tamaño del fruto y la concentración de sólidos solubles (CSS), varió entre localidades, sin embargo, el rendimiento relativo de los cultivares fue similar. Los cultivares mostraron diferencias significativas en los atributos relevantes para la industria y el consumidor: el color (de amarillo a naranja intenso), la CSS (de 8.7 a $14.7 \%$ ), la firmeza $(11.2$ a $32.8 \mathrm{~N}$ ) y el daño por enfriamiento después de almacenamiento refrigerado durante 18 días a $0{ }^{\circ} \mathrm{C}$ (de ninguno a leve) y después de 3 días adicionales a $20{ }^{\circ} \mathrm{C}$ (de ninguno a severo). Los cultivares como Diva, Fiji y Glamour presentaron atributos que los hacen especialmente valiosos para la industria de productos mínimamente procesados.

Palabras clave: Almacenamiento, Cucumis melo, color, daño por enfriamiento, firmeza, sólidos solubles.

Table 4. Chilling injury sensitivity of fruits of nine melon cultivars produced in Curacaví and Peñaflor (central Chile).

\begin{tabular}{|c|c|c|c|c|}
\hline \multirow[b]{2}{*}{ Cultivar } & \multicolumn{2}{|c|}{ Curacaví } & \multicolumn{2}{|c|}{ Peñaflor } \\
\hline & $18 \mathrm{~d}$ at $0^{\circ} \mathrm{C}$ & $18 \mathrm{~d}$ at $0^{\circ} \mathrm{C}+3 \mathrm{~d}$ at $20^{\circ} \mathrm{C}$ & $18 \mathrm{~d}$ at $0^{\circ} \mathrm{C}$ & $18 \mathrm{~d}$ at $0^{\circ} \mathrm{C}+3 \mathrm{~d}$ at $20^{\circ} \mathrm{C}$ \\
\hline Colima & $1.8^{2} \mathrm{a}^{3}$ & $3.3 \mathrm{a}$ & $1.5 \mathrm{~b}$ & $3.5 \mathrm{a}$ \\
\hline Diva & $0.6 \mathrm{~b}$ & $0.9 \mathrm{~cd}$ & $0.7 \mathrm{c}$ & $1.0 \mathrm{~b}$ \\
\hline Fiji & $0.0 \mathrm{c}$ & $0.0 \mathrm{e}$ & $0.0 \mathrm{~d}$ & $0.0 \mathrm{c}$ \\
\hline Glamour & $0.0 \mathrm{c}$ & $0.0 \mathrm{e}$ & $0.0 \mathrm{~d}$ & $0.0 \mathrm{c}$ \\
\hline HMX0592 & $0.0 \mathrm{c}$ & $0.1 \mathrm{de}$ & $0.0 \mathrm{~d}$ & $0.0 \mathrm{c}$ \\
\hline HMX9608 & $0.0 \mathrm{c}$ & $0.9 \mathrm{~cd}$ & $0.1 \mathrm{~d}$ & $1.4 \mathrm{~b}$ \\
\hline Navigator & $0.6 \mathrm{~b}$ & $1.2 \mathrm{bc}$ & $0.3 \mathrm{~cd}$ & $1.2 \mathrm{~b}$ \\
\hline PS 4038 & $0.9 \mathrm{~b}$ & $2.0 \mathrm{~b}$ & $2.2 \mathrm{a}$ & $3.3 \mathrm{a}$ \\
\hline Venezia & $0.5 \mathrm{bc}$ & $1.5 \mathrm{bc}$ & $0.5 \mathrm{~cd}$ & $0.8 \mathrm{bc}$ \\
\hline$P_{\text {value }}{ }^{1}$ & $<0.001$ & $<0.001$ & $<0.001$ & $<0.001$ \\
\hline
\end{tabular}

${ }^{1}$ Probability value from the analysis of variance.

${ }^{2}$ Chilling injury visual scale: 0 , no damage to traces ( $0-1 \%$ surface symptoms); 1 , mild (1.1 - 5\%); 2 , moderate (5.1 to $\left.15 \%\right)$; 3 , severe (15.1 - 30\%); and 4, extreme (>30\%).

${ }^{3}$ Means in the same column with different letter(s) are significantly different according to a least significant difference test $(\alpha \leq 0.05)$. 


\section{References}

Beaulieu, J.C. and J.R. Gorny. 2014. Fresh-cut fruits. In: K.C. Gross, C.Y. Wang and M. Saltveit (eds.). The commercial storage of fruits, vegetables, and florist and nursery stocks. Agriculture Handbook Number 66 (HB-66), draft updated August 2014. Available online at: http://www.ba.ars.usda.gov/ hb66/ (Website accessed: January 2015).

Cantwell, M. 2014. Overview of melon quality for fresh cut processing. Fresh Cut Lecture Notes, Courses Notes by UC Davis, UWI Lectures. Postharvest Quality. Available online at: http:// www.postharvestquality.com (Website accessed: December 2014).

Cook, R. 2014. Trends in the marketing of fresh produce and fresh-cut/value-added produce. Articles and presentations, Roberta Cook, Faculty, UC Davis Agriculture and Resource Economics. Available online at: http://agecon.ucdavis.edu/ (Website accessed: October 2014).

Dean, L. 2013. Growing Strong: Meeting consumer demand key to keeping fresh-cut healthy in 2013. Fresh Cut Magazine. Posted: 10 January 2013. Available online at: http://freshcut.com/ (Website accessed: August 2014).

Fallik, E., Y. Shalom, S. Alkalai-Tuvia, O. Larkov, E. Brandesis, and U. Ravid. 2005. External, internal and sensory traits in Galia-type melon treated with different waxes. Postharvest Biology and Technology 36:69-75.

Florkowski, W.J., R. L. Shewfelt, B. Brueckner, and S. E. Prussia. 2014. Postharvest Handling: A System Approach. 3th ed. Academic Press, San Diego, CA.

Fogelman, E., A. Kaplan, Z. Tanami, and I. Ginzberg. 2011. Antioxidative activity associated with chilling injury tolerance of muskmelon (Cucumis melo L.) rind. Scientia Horticulturae 128:267-273.

INE - Instituto Nacional de Estadísticas. 2010. Información Hortícola: Publicación especial 20082009. 11 Available on line at: http://www.odepa. cl/ (Web accessed December 2014).

Kader, A. 1999. Fruit maturity, ripening, and quality relationships. Proc. Int. Sym. on Effects of Pre and Postharvest Factors on Storage of Fruits. Ed. L. Michalczuk. Acta Horticulturae 485:203-208.

Kader, A.A. (Technical Editor). 2002. Postharvest Technology of Horticultural Crops. 3rd ed. Agriculture and Natural Resources. Publication 3311. University of California, Davis, CA.

Konica Minolta Sensing, Inc. 2007. Precise color communication. Color control from perception to instrumentation. Japan. $62 \mathrm{pp}$.

Krarup, C., J. Tohá, and R. González. 2009. Symptoms and sensitivity to chilling injury of cantaloupe melons during postharvest. Chilean Journal of Agricultural Research 69:125-133.

Krarup, C. 2010. Melones reticulados para procesados frescos: variabilidad y concepción de un arquetipo. VI Congreso Iberoamericano de Tecnología de Postcosecha y Agroexportaciones. Junio 2010, Mérida, México. Revista Iberoamericana de Tecnología Postcosecha 11:50 (Abstr.).

Laínez, D. and C. Krarup.2008. Caracterización en pre y poscosecha de dos cultivares de melón reticulado del tipo Oriental (Cucumis melo Grupo Cantalupensis). Ciencia e Investigación Agraria 35:59-66.

Munira, Z.A., S. Rosnah, O. Zaulia, and A.R. Russly. 2013. Effect of postharvest storage of whole fruit on physico-chemical and microbial changes of fresh-cut cantaloupe (Cucumis melo L. reticulatus cv. Glamour). International Food Research Journal 20:501-508.

Nuñez-Palenius, H., M. Gomez-Lim, N. OchoaAlejo, R. Grumet, G. Lester, and D.J. Cantliffe. 2008. Melon fruits: Genetic diversity, physiology, and biotechnology features. Critical Reviews in Biotechnology 28:13-55.

Ohashi, A., F.A. Al-Said, and I.A. Khan. 2009. Evaluation of different muskmelon (Cucumis melo) cultivars and production systems in Oman. International Journal of Agriculture and Biology 11:596-600.

Portela, S.I., and M.I. Cantwell. 1998. Quality changes of minimally processed honeydew melons stored in air or controlled atmosphere. Postharvest Biology and Technology 14:351-357.

Saha, S.K. and L. Sutterer, 2014. Southwest Indiana Muskmelon Variety Trial - 2013. p. 25-31. In: E. 
Maynard (ed.). Midwest Vegetable Trial Report for 2013. Purdue Univ., West Lafayette, IN.

Sakata, Y., and M. Sugiyama. 2002. Characteristics of Japanese cucurbits. Acta Horticulturae 588:195-203.

Sensoy, S., A. Ertek, I. Gedik, and C. Kucukyumuk. 2007. Irrigation frecuency and amount affect yield and quality of field-grown melon (Cucumis melo L.). Agricultural Water Management 88: 269-274.

Silveira, A.N., E. Aguayo, M. Chisari, and F. Artés. 2011. Calcium salts and heat treatment for quality retention of fresh-cut 'Galia' melon. Postharvest Biology and Technology 62:77-84.
Williams, T.V. and W. Roberts. 2002. Is vegetable variety evaluation and reporting becoming a lost art? An industry perspective. HortTechnology 12:553-559.

Yang, B., T. Shiping, L. Hongxia, Z. Jie, C. Jiankang, L. Yongcai, and Z. Weiyi. 2003. Effect of temperature on chilling injury, decay and quality of Hami melon during storage. Postharvest Biology and Technology 29:229-232.

Zeng, C., Z. Bie, and B. Yuan. 2009. Determination of optimum irrigation water amount for drip-irrigated muskmelon (Cucumis melo L.) in plastic greenhouse. Agricultural Water Management 96: 595-602. 
